\title{
A Preliminary Investigation into the Stability of Inorganic Arsenic Species in Laboratory Solutions Simulating Sediment Pore Water
}

\author{
Letitia Pillay* and Andrew Kindness \\ School of Chemistry \& Physics, University of KwaZulu-Natal, Private Bag X54001, Durban, 4000, South Africa.
}

Received 7 September 2015, revised 15 December 2015, accepted 20 December 2015.

\begin{abstract}
A simple method to preserve arsenic species in simulated pore water was investigated. Synthetic pore water containing high levels of $\mathrm{Fe}, \mathrm{Mn}$ and S (as sulfide, $\mathrm{S}^{2-}$ ) were synthesized and spiked with different arsenic species. Arsenite [As(III)], arsenate $[\mathrm{As}(\mathrm{V})]$, dimethylarsinate $\left[\left(\mathrm{CH}_{3}\right)_{2} \mathrm{AsO}^{2-}, \mathrm{DMA}\right]$, monomethylarsonate $\left[\left(\mathrm{CH}_{3}\right) \mathrm{AsO}_{3}{ }^{2-}, \mathrm{MMA}\right]$, monothioarsenate $(\mathrm{V})$ species $\left(\mathrm{AsO}_{3} \mathrm{~S}^{3-}, \mathrm{MTA}\right)$ and tetrathioarsenate(v) species $\left(\mathrm{AsS}_{4}{ }^{3-}, \mathrm{TTA}\right)$ in different combinations were used. Disodium ethylenediamine tetraacetate (EDTA) and temperature was used to preserve speciation. Solutions were analyzed at intervals of one day, week, month and 2 months after preparation. Samples were analyzed by HPLC-ICP-MS using an ion exchange column and ammonium carbonate buffer. Samples containing Fe and Mn spiked with As(III), As(V), DMA, MMA showed adequate species preservation for two months when EDTA was added. The total As in samples containing Fe, Mn and $\mathrm{S}^{2-}$ was preserved over 60 days however, speciation was not preserved. Samples spiked with synthesized mono- and tetra-thioarsenate(V) species showed immediate degradation of the mono- and tetra-thioarsenic species into unidentified As-S species. The results show that while EDTA may be adequate to preserve As species containing high Fe and Mn concentrations, the combination of EDTA and temperature was not successful in preserving As speciation in samples containing sulfides.
\end{abstract}

KEYWORDS

Arsenic speciation, EDTA, HPLC-ICP-MS, thioarsenic species.

\section{Introduction}

The toxicity of As species is well documented. ${ }^{1}$ Inorganic forms of arsenic are generally more toxic than the organic; the trivalent form generally more toxic than the pentavalent. There are several forms of As present in an aqueous ecosystem. The species, mobility and distribution of arsenic are determined by different factors; redox, methylation and adsorption processes. ${ }^{1 c, 2}$ Arsenic is both $\mathrm{pH}$ and redox sensitive. Under reducing and waterlogged conditions $(<200 \mathrm{mV})$, arsenite [As(III)] would be the predominant arsenic compounds. Inorganic arsenic is bound to metal oxides of $\mathrm{Fe}, \mathrm{Al}$ and $\mathrm{Mn}$ in sediments. Adsorption and precipitation of arsenic is dependent on the amount of clay minerals present and the soil $\mathrm{pH} .{ }^{2 \mathrm{~d}}$ Under reducing conditions, sulfide, Fe and As can form a number of complexes which precipitate out of the aqueous environment. However, As and sulfides may also form a number of different stable As-S complexes; thioarsenites. ${ }^{3}$ This has an impact on the solubility and mobility of As in the environment. Sulfide and Fe concentrations also play a significant role in the mobility of As; they form precipitates with As under reducing conditions.

The measurement of arsenic bioavailability and speciation gives the best indication of potential toxicity to an ecosystem. Traditional approaches to these measurements involve chemical extraction however, there are selectivity and over-extraction issues reported. ${ }^{4}$ An alternative method without the addition of chemical extractants is to measure the sediment pore water. Due to the close interaction of pore water with sediment, equilibrium between the two is achieved and valuable information about metal speciation in sediments and across the sediment water

* To whom correspondence should be addressed. E-mail: letitia.pillay@ gmail.com interface can be inferred. ${ }^{5}$ However, due to the complexity of most speciation measurements, on-site analysis is generally not possible and there is typically some delay before measurements can be carried out. Therefore, a successful method to preserve metal speciation, particularly with arsenic, prior to analysis is important to ensure the accuracy of the results obtained.

The measurement of As species present in pore water cannot be undertaken without an adequate preservation method since arsenic is light sensitive, redox and $\mathrm{pH}$ active. ${ }^{2 \mathrm{c}} \mathrm{A}$ number of detailed studies have been carried out to assess the success of complexing agents, ion exchange resins, acidification, temperature and opaque storage vessels as preservation agents for As species. ${ }^{6}$ Most of these studies measure the stability of As(III), arsenate $[\mathrm{As}(\mathrm{V})]$, dimethylarsinate $(\mathrm{V})\left[\left(\mathrm{CH}_{3}\right)_{2} \mathrm{AsO}^{2-}, \mathrm{DMA}\right]$, monomethylarsonate $(\mathrm{V})\left[\left(\mathrm{CH}_{3}\right) \mathrm{AsO}_{3}{ }^{2-}, \mathrm{MMA}\right]$ in natural or synthetic water or on acid mine drainage samples. A number of studies have reported success with $\mathrm{H}_{3} \mathrm{PO}_{4}$ used in combination with low temperature for $\mathrm{As}(\mathrm{III}), \mathrm{As}(\mathrm{V}), \mathrm{DMA}, \mathrm{MMA} .^{2 \mathrm{c}, 7}$ Cation exchange resins as a clean-up stage prior to acidification on acid mine drainage samples, which contain high $\mathrm{Fe}, \mathrm{Mn}$ and $\mathrm{Al}$ content has also been reported to be successful. ${ }^{8}$ Acidification has also been reported to result in poor preservation for As-S species. $^{9}$

Other acidification preservation methods investigated included the addition of ascorbic acid, $\mathrm{HCl}, \mathrm{HNO}_{3}$ and $\mathrm{H}_{2} \mathrm{SO}_{4}{ }^{7 b, 10}$ These methods were not suitable for this study and were disregarded for a number of reasons. Ascorbic acid has been shown to oxidize As(III) in natural water. ${ }^{11} \mathrm{HCl}$ was not suitable where the method for detection is ICP-MS. $\mathrm{HNO}_{3}$ is a strong oxidizing agent and while $\mathrm{H}_{2} \mathrm{SO}_{4}$ worked well in synthetic samples it was a poor 
preservative of speciation in natural samples. ${ }^{2 b, 8,12}$ Disodium ethylenediamine tetraacetate (EDTA) is the most commonly used preserving agent. ${ }^{2 b, 7 b, 8,12-13}$ EDTA complexes the Fe, Mn and $\mathrm{Al}$ cations preventing their interaction with As and the subsequent precipitation of the complexes formed. EDTA is the preferred preservation agent when using chromatography. ${ }^{10}$

The influence of EDTA and low storage temperature on the stability of inorganic As species in synthesized pore water was investigated. These two parameters are simple to control and could be easily administered to samples in the field. The synthesized pore water contained high amounts of Fe and $\mathrm{S}^{2-}$ (to mimic the upper levels found in estuaries) and their effect on As speciation was also investigated. Only these three elements were chosen as their presence in natural environments is key to As speciation and mobility. In natural systems, there would be a larger range of parameters and equilibrium dynamics to consider, thus this investigation is seen as a preliminary investigation of a simplified system. However, it is believed that the variable studied are key to understanding the preservation of arsenic species in natural water samples.

\section{Experimental}

Stock $1000 \mathrm{mg} \mathrm{kg}^{-1}$ solutions of Fe(II) and Mn(II) (Fluka) were used for the synthetic pore water samples (AR grade). A $0.5 \mathrm{M}$ EDTA (BDH) stock solution was prepared. A $1000 \mathrm{mg} \mathrm{kg}^{-1} \mathrm{~S}^{2-}$ solution was made from $\mathrm{Na}_{2} \mathrm{~S}$ (JT Baker).

The synthesized pore water solutions were chosen using literature values of the upper levels of $\mathrm{Fe}, \mathrm{Mn}$ and $\mathrm{S}$ commonly found in estuarine systems. ${ }^{14}$

The following synthesized pore water solutions were prepared:

$\mathrm{A}=10 \mathrm{mg} \mathrm{L}^{-1} \mathrm{Fe}$ and $1 \mathrm{mg} \mathrm{L}^{-1} \mathrm{Mn}$

$\mathrm{B}=10 \mathrm{mg} \mathrm{L}^{-1} \mathrm{Fe}+1 \mathrm{mg} \mathrm{L}^{-1} \mathrm{Mn}+0.025 \mathrm{M}$ EDTA,

$\mathrm{C}=10 \mathrm{mg} \mathrm{L}^{-1} \mathrm{Fe}+1 \mathrm{mg} \mathrm{L}^{-1} \mathrm{Mn}+50 \mathrm{mg} \mathrm{L}^{-1} \mathrm{~S}^{2-}$

$\mathrm{D}=10 \mathrm{mg} \mathrm{L}^{-1} \mathrm{Fe}+1 \mathrm{mgL}^{-1} \mathrm{Mn}+50 \mathrm{mg} \mathrm{L}^{-1} \mathrm{~S}^{2-}+0.025 \mathrm{MEDTA}$

The EDTA concentration was chosen to provide a molar excess of EDTA in the solution thus ensuring complete chelation of Fe. Each solution was divided into two aliquots and each aliquot spiked with either a solution containing approximately $50 \mu \mathrm{g} \mathrm{L}^{-1}$ of DMA, MMA, As(III) and As(V) or a solution containing $100 \mu \mathrm{g} \mathrm{L}^{-1} \mathrm{MTA}$ and $100 \mu \mathrm{g} \mathrm{L}^{-1}$ TTA in the final solution volume. Arsenic standards were made from $\mathrm{As}_{2} \mathrm{O}_{3}$ [As(III)] and $\mathrm{Na}_{2} \mathrm{HAsO}_{4} \cdot 7 \mathrm{H}_{2} \mathrm{O}[(\mathrm{As}(\mathrm{V})]$, disodium monomethyl arsenate [monomethylarsenate(v)] (ChemService, USA) and sodium cacodylate dimethylarsenite(v) (Strem, USA).

Mono- and tetra-thioarsenate were synthesized according to Stauder et al. ${ }^{3 \mathrm{c}}$ The synthesis was confirmed by ICP-MS. After spiking with As species, sample aliquots were stored in plastic Eppendorf vials and frozen at $-20^{\circ} \mathrm{C}$. Prior to analysis, samples were thawed and diluted $1: 1$ with $10 \mathrm{mM}$ ammonium carbonate. Samples were centrifuged at $6000 \mathrm{rpm}$ for $5 \mathrm{~min}$ and analyzed by HPLC-ICP-MS. Duplicate analysis were carried out where possible.

\subsection{Instrumentation}

HPLC separation of species was carried out using an Agilent 1100 series HPLC with an IonPac AS14A column. The mobile phase was $100 \mathrm{mM}$ ammonium carbonate adjusted to $\mathrm{pH} 10$ with conc. ammonia. A constant flow rate of $1 \mathrm{~mL} \mathrm{~min}{ }^{-1}$ was maintained throughout each run. One hundred micro-litres of sample or standard was injected onto the column. The following gradient elution was applied; $10 \mathrm{mM}$ of the mobile phase for $7 \mathrm{~min}$ followed by a ramp to $100 \mathrm{mM}$ ammonium carbonate over $10 \mathrm{~min}$. The $100 \mathrm{mM}$ was held for $7 \mathrm{~min}$ before a decrease to $10 \mathrm{mM}$ over $6 \mathrm{~min}$. The total run time was $30 \mathrm{~min}$. Inorganic As was measured in the separated analytes using the Agilent $7500 \mathrm{c}$ ICP-MS with a $100 \mu \mathrm{g} \mathrm{L}^{-1} \mathrm{Rh}$ internal standard.

Calculations for arsenic species were based on DMA calibration curves. A concentration range of $10-200 \mu \mathrm{g} \mathrm{L} \mathrm{L}^{-1}$ DMA was used. The response of the DMA signal to gradient elution was calculated to account for changes over the analysis time. A series of injections of a $100 \mu \mathrm{g} \mathrm{L}^{-1}$ DMA standard were carried out every 2.73 min over the separation method outlined above to determine signal changes.

Collision Cell-ICP-MS using $\mathrm{O}_{2}$ was carried out to quantify the As:S ratio of the thioarsenic species synthesized. ICP-MS conditions using a dynamic reaction cell with $\mathrm{O}_{2}$ in the collision cell were as previously established..$^{15}$

\section{Results and Discussion}

\subsection{Synthesis of Mono- and Tetra-thioarsenate}

Synthesized mono-thioarsenate was analyzed by HPLC-ICP-MS using an oxygen collision cell to confirm quantify the As:S mole ratios obtained for the As-S crystals. In addition to $m / z 91$ for arsenic oxide, $m / z 48$ was monitored for sulfur-oxide. The data confirms the formation of an As-S species (Fig. 1). A 1:1.06 \pm 0.09 As to $\mathrm{S}$ molar ratio for the MTA species was calculated $(n=3$, $\%$ RSD $=8$ ). No confirmation of molar ratio was carried out on the synthesized tetra-thioarsenate.

\subsection{Separation of As Species}

Standards of all As species measured under listed condition showed good separation with As-S species appearing after $800 \mathrm{~s}$ (Fig. 2). Retention times were confirmed at the beginning of each set of analyses.

\subsection{As Speciation in Solution A and B Spiked with $50 \mu \mathrm{g} \mathrm{L}^{-1}$ DMA, MMA, As(III) and As(V)}

Solutions containing no EDTA (Table 1a) show an immediate loss of As(III). This loss of As(III) indicates the immediate reaction between As and Fe to form As-Fe precipitates which are not eluted from the column. A visible Fe precipitate was present on storage vials upon removal from the fridge. In addition, As(III) is oxidized to $\mathrm{As}(\mathrm{V})$ as shown by the increased initial As(V) concen-

Table 1 Concentrations of As species $\left(\mu \mathrm{g} \mathrm{L}^{-1}\right)$ in the spiked Solution A with (b) and without EDTA (a)

a) Solution A with $50 \mu \mathrm{g} \mathrm{L}^{-1} \mathrm{As}(\mathrm{V}), \mathrm{As}(\mathrm{III})$, DMA and MMA ( $n=2$, RSD $<8 \%$ )

\begin{tabular}{lcccr}
\hline Days & Initial & 1 & 7 & 60 \\
\hline DMA & 50.8 & 57.55 & 49.26 & 47.02 \\
As(III) & 50.9 & 0 & 0 & 2.67 \\
MMA & 51.9 & 35.43 & 31.16 & 28.44 \\
As(V) & 51.1 & 68.2 & 55.90 & 40.65 \\
$\Sigma$ As & 205 & 161.2 & 136.3 & 118.8 \\
\hline
\end{tabular}

b) Solution B with $50 \mu \mathrm{g} \mathrm{L}^{-1} \mathrm{As}(\mathrm{V}), \mathrm{As}(\mathrm{III})$, DMA and MMA $(n=2$, RSD $<6 \%)$

\begin{tabular}{lcccc}
\hline Days & Initial & 1 & 7 & 60 \\
\hline DMA & 50.8 & 54.88 & 44.24 & 44.05 \\
As(III) & 50.9 & 38.50 & 27.48 & 30.28 \\
MMA & 51.9 & 38.59 & 30.46 & 26.58 \\
As(V) & 51.1 & 76.06 & 74.51 & 57.76 \\
$\Sigma$ As & 205 & 208.0 & 176.7 & 158.7 \\
\hline
\end{tabular}



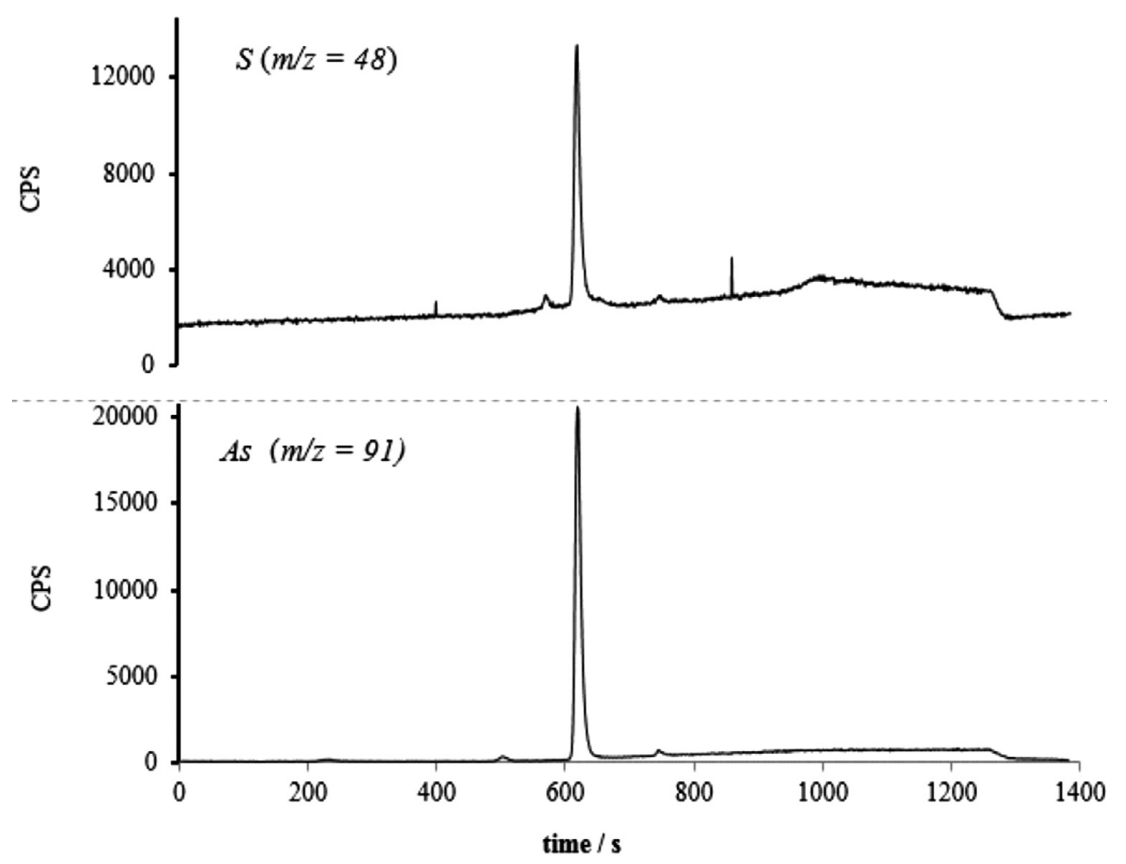

Figure 1 Chromatogram of the synthesized monothioarsenate crystals with matching retention times for As and S by HPLC-ICP-MS. HPLC conditions: 10-100 mM ammonium carbonate ( $\mathrm{pH} \mathrm{10)} \mathrm{for} 17 \mathrm{~min}, 100 \mathrm{mM}$ ammonium carbonate ( $\mathrm{pH} 10$ ) between 17 and $24 \mathrm{~min}$.

tration. The addition of EDTA stabilises As(III) preventing the initial conversion to As-Fe precipitates (Table 1b); however, conversion between species does still occur over time. It is also possible that the increased initial $\mathrm{As}(\mathrm{V})$ concentration is as a result of oxidation of the sample during the sample analysis.

Both sets of data show loss of As species over the 2-month analysis period. The results indicate that DMA and MMA remain relatively stable over the 2 months. No other As products were observed during the chromatographic analysis. This trend is similar to two other studies carried out measuring As species in groundwater and acid mine drainage samples. ${ }^{7 \mathrm{ba}}$ The addition of EDTA does inhibit the loss of As species to a limited extent (approximately $4 \%$ ).

\subsection{As Speciation in Solution $C$ and D Spiked with} $50 \mu \mathrm{g} \mathrm{L}^{-1} \mathrm{As}(\mathrm{V})$, As(III), DMA, MMA

A number of studies have indicated the formation of thioarsenic species in waters containing sulfide, e.g. geothermal

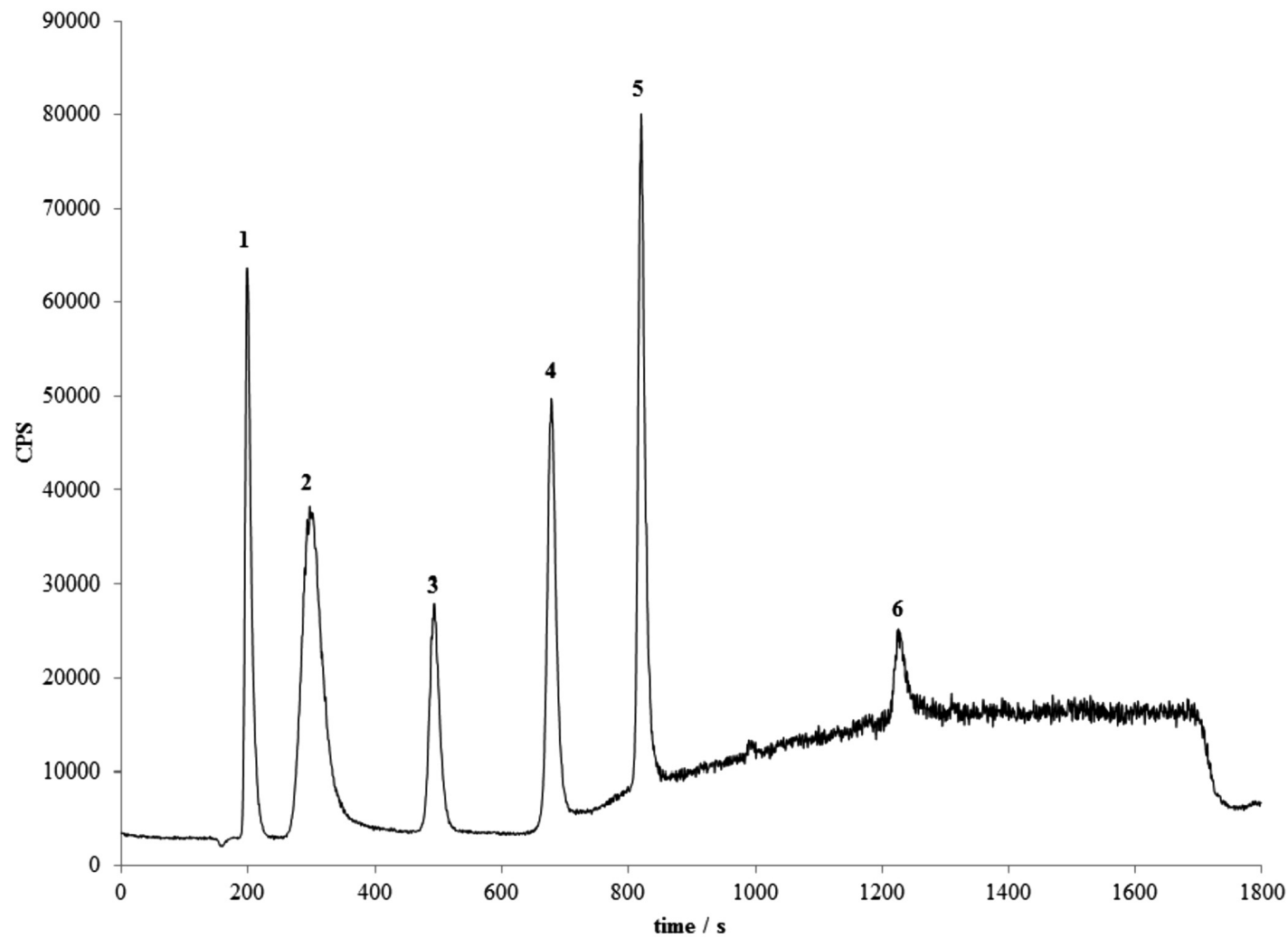

Figure 2 Chromatographic separation of the different As species. (1 = DMA (200 s), 2 = As(III) (304 s), $3=$ MMA (495 s), $4=$ As(V) $(679 \mathrm{~s})$, $5=$ monothioarsenate $(821 \mathrm{~s}), 6=$ tetrathioarsenate $(1230 \mathrm{~s}))$.monothioarsenate $(821 \mathrm{~s}), 6=$ tetrathioarsenate $(1230 \mathrm{~s}))$. 
water and acid mine drainage (AMD) samples. . $^{3 b, 3 c, 7 b, 8 b, 16}$ These report that a range of thioarsenic species are formed in water with high sulfide content. The formation and subsequent stability of thioarsenic species are conditional on $\mathrm{pH}$ and redox.

The formation of As-S species was observed in solution $\mathrm{C}$ which contained no EDTA (Table 2). In addition, a precipitate in the storage vials indicated that the free Fe had reacted with As species causing precipitation. Without EDTA, none of the As species was stable. The changes in As species concentrations over the study period also suggest a cycle of reactions, decomposition, reformation and precipitation occurring. Over time, thioarsenic products form and other As species degrade. A poor mass balance correlation was obtained since not all As-S species were detected or identified and the precipitation of As reacting with $\mathrm{Fe}$, As and $\mathrm{S}^{2-}$.

The addition of EDTA was effective in the preservation of total As over a 60-day period (Table 3). EDTA complexes with Fe and $\mathrm{Mn}$ forming chelates preventing $\mathrm{Fe}-\mathrm{As}$ precipitates forming thus preserving the free As species. As(v), DMA and MMA species remained relatively stable over the measurement period. The absence of As(III) by week 1 is suggested to be due to the reaction between arsenite and the free S. In addition As(III) would also be subject to oxidation in the presence of un-complexed Fe(II). The loss of As(III) is complete within a week and a corresponding increase in the thioarsenic species is noted.

Table 2 Concentrations of As species $\left(\mu \mathrm{g} \mathrm{L}^{-1}\right)$ in the spiked Solution $\mathrm{C}$ $(n=2$, RSD $<2 \%)$.

\begin{tabular}{lcccc}
\hline Days & Initial & 1 day & 7 days & 60 days \\
\hline DMA & 50.8 & 40.1 & 1.42 & 1.06 \\
As(III) & 50.9 & 1.82 & 16.6 & 17.2 \\
MMA & 51.9 & 23.1 & 6.87 & 2.22 \\
As(V) & 51.1 & 19.8 & 20.9 & 3.94 \\
$\Sigma$ As-S* & - & 0 & 171.9 & 37.4 \\
Total As & 205 & 85 & 218 & 62 \\
\hline
\end{tabular}

* Formation of several thioarsenic species.
MTA was the predominant species formed followed by two other unidentified As-S species. There is a correlation between the loss of As(III) and (V) and the formation of the thioarsenate species.

\subsection{As Speciation in Pore Water Solution D Spiked with $100 \mu \mathrm{g} \mathrm{L}^{-1}$ MTA and TTA}

The addition of EDTA to preserve the As species in synthesized pore water samples spiked with mono- and tetra-thioarsenate was unsuccessful. Samples analyzed within an hour of being prepared showed As species other than the MTA and TTA. Stability was therefore not monitored over 60 days but at five time intervals in a 24 -hour period (1,3, 5, 8 and $24 \mathrm{~h})$ using single injections. The thioarsenic species have been identified as the thioarsenate and not thioarsenite species that would be expected in an anoxic system. Similar findings have been reported when investigating thioarsenates in geothermal water and groundwater respectively. ${ }^{3 \mathrm{~b}, 3 \mathrm{c}}$

Mono- and tetra-thioarsenate spiked solutions showed poor stability of the As species. Degradation of the thioarsenic species was immediate (Fig. 3). As(III), As(V), and two unidentified thioarsenate products form over the period of time. $100 \mu \mathrm{g} \mathrm{L}^{-1}$ of mono and TTA were expected in the initial solutions. However, the low concentration of MTA and the absence of TTA indicate the decomposition of the synthesized compounds in both the

Table 3 Concentrations of As species $\left(\mu \mathrm{g} \mathrm{L}^{-1}\right)$ in the spiked Solution D $(n=2, \operatorname{RSD}<5 \%)$

\begin{tabular}{lcccr}
\hline Days & Initial & 1 & 7 & 60 \\
\hline DMA & 50.8 & 46.54 & 48.54 & 50.13 \\
As(III) & 50.9 & 22.88 & 0 & 4.80 \\
MMA & 51.9 & 34.76 & 32.25 & 31.18 \\
As(V) & 51.1 & 82.86 & 69.35 & 75.50 \\
$\Sigma$ As-S & - & 3.38 & 30.53 & 30.93 \\
Total As & 205 & 190.4 & 180.7 & 192.5 \\
\hline
\end{tabular}

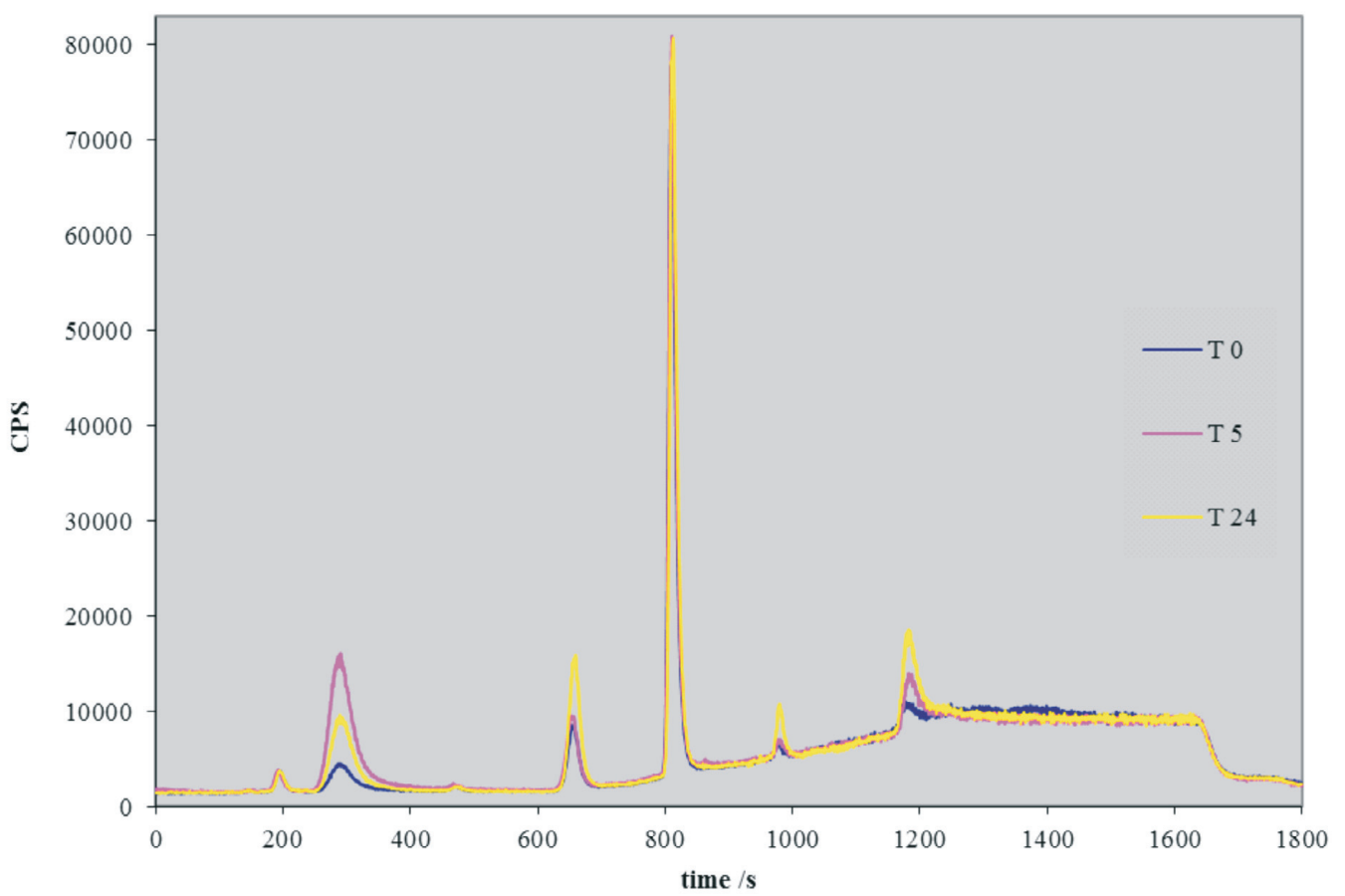

Figure 3 Chromatogram showing degradation of thioarsenates over 24 hours at three time points, 30 min (T0), 5 hours (T5) and 24 hours (T24) $1=\operatorname{As}(\mathrm{III}) 2=\operatorname{As}(\mathrm{V}) 3=$ monothioarsenate $4=$ Unknown $15=$ tetrathioarsenate. 
standards and in the tested solutions. In addition, both the monoand the tetra-thioarsenate species decompose to form arsenate and an unknown As-S species ${ }^{17}$ Samples with a $\mathrm{pH}$ lower than 6 resulted in the reduction of TTA to arsenite and sulfur species. Typically TTA species predominate only in sulfide concentrations greater than $10^{-2} \mathrm{M} \mathrm{S}^{2-}$ however the current study has an upper limit of $10^{-3} \mathrm{M} \mathrm{S}^{2-} \cdot 3 \mathrm{~b}, 16 \mathrm{~b}, 18$ Thus the mono- and tetra-arsenic species react with free sulfide forming other As-S complexes which may precipitate in the column. MTA can also undergo reactions to form other thioarsenate species. ${ }^{3 c, 19}$ The changes in As(III) and As(V) concentrations indicate the cycling of the As species and the formation and degradation of As-S products as time passes. The eluent $\mathrm{pH}$ was maintained at 10 as this has been reported to maintain thioarsenic species and this could have brought about further changes to the speciation on the column.

\section{Conclusions}

EDTA can be effectively used to preserve the total As in solutions containing $\mathrm{Fe}, \mathrm{Mn}$ and $\mathrm{S}^{2-}$ at levels typically found in estuarine conditions. The addition of EDTA to complex Fe and Mn prevented the formation of Fe and Mn-As species. A $20 \%$ loss of As species is recorded over the 2-month period for both solutions with and without sulfides. Samples without EDTA showed poor stability displaying a loss of As speciation as well as a 40-70\% loss of total As measured This was due to reactions between the free As and sulfide species forming monothioarsenate or other thioarsenate products. This data shows that at high concentrations of sulfide, e.g. $50 \mathrm{mg} \mathrm{L}^{-1}$, a different type of pretreatment is necessary if thioarsenic species are to be preserved. In other studies, cryo-freezing samples under anaerobic conditions have shown some promise in groundwater samples contaminated with arsenic and may provide a suitable alternative to EDTA and temperature.

\section{Acknowledgements}

This work is based on research supported in part by the National Research Foundation (NRF) of South Africa under the Thuthuka Programme Grant Number 66346 and the University of KwaZulu-Natal Leadership and Equity Advancement Programme (LEAP). The authors wish to thank Prof. Joerg Feldmann (University of Aberdeen) for access to his laboratory and equipment.

\section{References}

1 a) W.R. Cullen and K.J. Reimer, Arsenic speciation in the environment, Chem. Rev., 1989, 89, 52; b) V.K. Sharma and M. Sohn, Aquatic arsenic: Toxicity, speciation, transformations, and remediation, Environ. Int., 2009, 35, 743-759; c) P.L. Smedley and D.G. Kinniburgh, A review of the source, behaviour and distribution of arsenic in natura waters, Appl. Geochem., 2002,17,517-568; d) M. Vahter, Mechanisms of arsenic biotransformation, Toxicol., 2002, 181, 211-217; e) B. Sadee, M.E. Foulkes and S.J. Hill, Coupled techniques for arsenic speciation in food and drinking water: a review, J. Anal. At. Spectrom., 2015, 30, 102-118.

2 a) T. Petänen, University of Helsinki (Helsinki), 2001; b) A.J. Bednar, J.R. Garbarino, J.F. Ranville and T.R. Wildeman, Preserving the distribution of inorganic arsenic species in groundwater and acid mine drainage samples, Environ. Sci. Technol., 2002, 36, 2213-2218; c) B. Daus, H. Weiss, J. Mattusch and R. Wennrich, Preservation of arsenic species in water samples using phosphoric acid - Limitations and long-term stability, Talanta, 2006, 69, 430-434; d) A.R. Keimowitz, Y Zheng, S.N. Chillrud, B. Mailloux, H. B. Jung, M. Stute and H.J. Simpson, Arsenic redistribution between sediments and water near a highly contaminated source, Environ. Sci. Technol., 2005, 39, 8606-8613; e) J.C. Raposo, O. Zuloaga, J. Sanz, U. Villanueva, P. Crea N. Etxebarria, M.A. Olazabal and J.M. Madariaga, Analytical and thermodynamical approach to understand the mobility/retention of arsenic species from the river to the estuary. The Bilbao case study, Mar. Chem., 2006, 99, 42-51.
3 a) P.A. O'Day, D. Vlassopoulos, R. Root and N. Rivera, The influence of sulfur and iron on dissolved arsenic concentrations in the shallow subsurface under changing redox conditions, Proc. Nat. Acad. Sci. USA, 2004, 101, 13703-13708; b) B. Planer-Friedrich, J. London, R.B. McCleskey, D.K. Nordstrom and D. Wallschlager, Thioarsenates in geothermal waters of Yellowstone National Park: determination, preservation, and geochemical importance, Environ. Sci. Technol., 2007, 41, 5245-5251; c) S. Stauder, B. Raue and F. Sacher, Thioarsenates in sulfidic waters, Environ. Sci. Technol., 2005, 39, 5933-5939; d) D. Wallschlager and C.J. Stadey, Determination of (oxy)thioarsenates in sulfidic waters, Anal. Chem, 2007, 79, 3873-3880.

4 a) J.R. Bacon and C.M. Davidson, Is there a future for sequential chemical extraction?, Analyst, 2008, 133, 25-46; b) C.R.M. Rao, A. Sahuquillo and J.F.L. Sanchez, A review of the different methods applied in environmental geochemistry for single and sequential extraction of trace elements in soils and related materials, Water Air Soil Pollut., 2008, 189, 291-333.

5 G. Bally, V. Mesnage, J. Deloffre, O. Clarisse, R. Lafite and J.P. Dupont, Chemical characterization of porewaters in an intertidal mudflat of the Seine estuary: relationship to erosion-deposition cycles, Mar. Pollut. Bull., 2004, 49, 163-173.

6 B. Radke, L. Jewell and J. Namiesnik, Analysis of arsenic species in environmental samples, Crit. Rev. Anal. Chem., 2012, 42, 162-183.

7 a) S.D. Conklin, M.W. Fricke, P.A. Creed and J.T. Creed, Investigation of the $\mathrm{pH}$ effects on the formation of methylated thio-arsenicals, and the effects of $\mathrm{pH}$ and temperature on their stability, J. Anal. At. Spectrom., 2008, 23, 711-716; b) Y.T. Kim, H. Yoon, C. Yoon and N.C. Woo, An assessment of sampling, preservation, and analytical procedures for arsenic speciation in potentially contaminated waters, Environ. Geochem. Health, 2007, 29, 337-346.

8 a) V. Oliveira, A.M. Sarmiento, J.L. Gomez-Ariza, J.M. Nieto and D. Sanchez-Rodas, New preservation method for inorganic arsenic speciation in acid mine drainage samples, Talanta, 2006, 69, 1182-1189; b) D. Sanchez-Rodas, V. Oliveira, A.M. Sarmiento, J.L. Gomez-Ariza and J.M. Nieto, Preservation procedures for arsenic speciation in a stream affected by acid mine drainage in southwestern Spain, Anal. Bioanal. Chem., 2006, 384, 1594-1599.

9 D. Wallschlager and J. London, Determination of methylated arsenicsulfur compounds in groundwater, Environ. Sci. Technol., 2008, 42, 228-234.

10 R.B. McCleskey, D.K. Nordstrom and A.S. Maest, Preservation of water samples for arsenic(III/V) determinations: an evaluation of the literature and new analytical results, Appl. Geochem., 2004, 19, 995-1009.

11 Z. Gong, X. Lu, M. Ma, C. Watt and X.C. Le, Arsenic speciation analysis, Talanta, 2002, 58, 77-96.

12 G.E.M. Hall, J.C. Pelchat and G. Gauthier, Stability of inorganic arsenic(III) and arsenic(V) in water samples, J. Anal. At. Spectrom., 1999, 14, 205-213.

13 P.A. Gallagher, C.A. Schwegel, A. Parks, B.M. Gamble, L. Wymer and J.T. Creed, Preservation of As(III) and As(V) in drinking water supply samples from across the United States using EDTA and acetic acid as a means of minimizing iron-arsenic coprecipitation, Environ. Sci. Technol., 2004, 38, 2919-2927.

14 a) P.A. O'Day, S.A. Carroll, S. Randall, R.E. Martinelli, S.L. Anderson, J. Jelinski and J.P. Knezovich, Metal speciation and bioavailability in contaminated estuary sediments, Alameda Naval Air Station, California, Environ. Sci. Technol., 2000, 34, 3665-3673; b) P. Sullivan and K.G. Taylor, Sediment and porewater geochemistry in a metal contaminated estuary, Dulas Bay, Anglesey, Environ. Geochem. Health, 2003, 25, 115-122; c) K.W. Warnken, G.A. Gill, L.L. Griffin and P.H. Santschi, Sediment-water exchange of $\mathrm{Mn}, \mathrm{Fe}, \mathrm{Ni}$ and $\mathrm{Zn}$ in Galveston Bay, Texas, Mar. Chem., 2001, 73, 215-231; d) G. Simpson and I. Hutcheon, Porewater chemistry and diagenesis of the modern Fraser River Delta, J. Sedim. Res., 1995, A65, 8.

15 K. Bluemlein, A. Raab, A. Meharg, J. Charnock and J. Feldmann, Can we trust mass spectrometry for determination of arsenic peptides in plants: comparison of LC-ICP-MS and LC-ES-MS/ICP-MS with XANES/EXAFS in analysis of Thunbergia alata, Anal. Bioanal. Chem., 2008, 390, 1739-1751.

16 a) B. Planer-Friedrich and D. Wallschlager, A critical investigation of hydride generation-based arsenic speciation in sulfidic waters, Environ. Sci. Technol., 2009, 43, 5007-5013; b) R.T. Wilkin, D. Wallschlager and R.G. Ford, Speciation of arsenic in sulfidic waters, Geochem. Trans., 2003, 4, 1-7. 
17 G. Schwedt and M. Rieckhoff, Separation of thio- and oxothioarsenates by capillary zone electrophoresis and ion chromatography, J. Chromatogr. A, 1996, 736, 341-350.

18 E. Suess, A.C. Scheinost, B.C. Bostick, B.J. Merkel, D. Wallschlaeger and B. Planer-Friedrich, Discrimination of thioarsenites and thioarse- nates by X-ray absorption spectroscopy, Anal. Chem., 2009, 81, $8318-8326$.

19 J.C. Fisher, D. Wallschlaeger, B. Planer-Friedrich and J.T. Hollibaugh, A new role for sulfur in arsenic cycling, Environ. Sci. Technol., 2007, 42, $81-85$. 